\title{
Effect of integrated nutrient management and spacing on seed quality parameters of black gram cv. Lbg-625 (rashmi)
}

\author{
N. Amruta ${ }^{*}$ P. J. Devaraju, Mangalagowri, S. P. Kiran, H. P. Ranjitha and Kalavati \\ Teli
}

Department of Seed Science and Technology, University of Agricultural Sciences, Bengaluru- 560065 (Karnataka), INDIA

*Corresponding author. E-mail: amrutha.ngowda@gmail.com

Received: July 2, 2015; Revised received: October 9, 2015; Accepted: March 4, 2016

\begin{abstract}
A field experiment was conducted to assess the response of nutrient levels and spacing on seed quality attributes of black gram cv. LBG-625 (Rashmi). Experimental results revealed that fertilizer application of 50:100:100 + Black gram rhizobia (250 $\left.\mathrm{g} \mathrm{ha}^{-1}\right)+$ PSB- Bacillus megaterium $\left(250 \mathrm{~g} \mathrm{ha}^{-1}\right)$ recorded highest test weight (39.27 g), germination $(90.60 \%)$, root length $(15.77 \mathrm{~cm})$, shoot length $(13.43 \mathrm{~cm})$, mean seedling length $(29.20 \mathrm{~cm})$, mean seedling dry weight $(57.99 \mathrm{mg})$, seedling vigour index-I (2656), seedling vigour index-II (525), total dehydrogenase activity $(0.998)$, protein content $(23.16 \%)$, field emergence $(86.56 \%)$ lowest electrical conductivity $\left(0.813 \mathrm{dSm}^{-1}\right)$ were superior over other fertilizer treatments. Among the planting geometry $60 \times 10 \mathrm{~cm}$ recorded more germination per cent $(90.48 \%)$ compared to $45 \times 10 \mathrm{~cm}(87.64 \%)$ and $30 \times 10 \mathrm{~cm}(86.91 \%)$. Interaction of nutrient levels and spacing through the application of 50:100:100 + black gram rhizobia (250 $\left.\mathrm{g} \mathrm{ha}^{-1}\right)+$ PSB- B. megaterium $\left(250 \mathrm{~g} \mathrm{ha}^{-1}\right)$ with planting geometry $60 \times 10 \mathrm{~cm}$ recorded more mean seedling length $(34.40 \mathrm{~cm})$, mean seedling dry weight $(58.30 \mathrm{mg})$, and field emergence $(90.24 \%)$ lowest electrical conductivity $\left(0.776 \mathrm{dSm}^{-1}\right)$ compared to control. The application of $50: 100: 100+$ Black gram rhizobia $\left(250 \mathrm{~g} \mathrm{ha}^{-1}\right)+$ PSB- B. megaterium $\left(250 \mathrm{~g} \mathrm{ha}^{-1}\right)$ with planting geometry $60 \times 10 \mathrm{~cm}$ were considered as seed quality improvement approach in blackgram, therefore conjunctive use of inorganic fertilizers and biofertilizer may be suggested for higher seed quality parameters along with overall betterment of crop.
\end{abstract}

Keywords: Black gram, rhizobia, PSB- Bacillus megaterium, nutrient levels

\section{INTRODUCTION}

Black gram (Vigna mungo L. Hepper) is one of the most important pulse crop among the various grain legumes. According to Vavilov (1951) it is native to India, belong to the family leguminaceae. It contains about 26 percent protein, 1.2 per cent fat and 56.6 per cent carbohydrates on dry weight basis and it is rich source of calcium and iron. The basic concept of integrated nutrient management is the supply of required plant nutrient for sustaining the desired crop productivity with minimum deleterious effect on soil health environment. Integrated nutrient management intended for four major goals to be achieved. They are to maintain soil productivity, to ensure sustainable productivity, to prevent degradation of the environment and to reduce the expenditure on the cost of chemical fertilizers (Balasubramanian, 1999).

However, application of excessive nutrients led to declining nutrient-use efficiency making fertilizer consumption uneconomical and producing adverse effects on atmosphere (Aulakh and Adhya 2005) and groundwater quality (Aulakh et al. 2009) causing health hazards and climate change. On other hand, nutrient mining has occurred in many soils due to lack of affordable fertilizer sources and where fewer or no organic residues are returned to the soils. Soils of Karnataka are inherently poor in organic matter, fertility and water-holding capacity. In these soils, N, P and $\mathrm{S}$ deficiencies are principal yield-limiting factors and maintaining seed quality. INM, which entails the maintenance of soil fertility to an optimum level for crop productivity to obtain the maximum benefit from all possible sources of plant nutrients - organics as well as inorganics - in an integrated manner (Aulakh and Grant 2008; Sangeeta et al., 2014), is an essential step to address the twin concerns of nutrient excess and nutrient depletion. INM is also important for marginal farmers who cannot afford to supply crop nutrients through costly chemical fertilizers (Aulakh et al., 2009).

Therefore, the aforesaid consequences have paved way to increase the productivity of crops using the combination of inorganic sources and biofertilizers. Thus, integrated approach of nutrient supply by chemical fertilizers along with biofertilizers is gaining importance as this system not only reduces the use of excessive use of inorganic fertilizers, but sustaining the 
crop productivity by improving soil health and is also an environment-friendly approach. Integration of inorganic fertilizers and biofertilizers resulted in better growth, yield and nutrient uptakes in black gram (Kumpawat, 2010), green gram (Mandal and Pramanick, 2014) and rice (Kumar et al., 2014) as compared to sole application of inorganic fertilizers. However, information on the conjunctive use of inorganic fertilizers and biofertilizers is lacking in many crops including black gram. The optimum plant density can provide congenial conditions to have maximum light interruption right from early growth stage to pod filling stage. By changing the plant spacing, it is possible to achieve optimum vegetative and reproductive growth to boost up crop productivity per unit area (Anilkumar, 2004). In view of the above facts the present investigation carried out to study the influence of integrated nutrient management and spacing on growth parameters of black gram cv. LBG 625 (Rashmi).

\section{MATERIALS AND METHODS}

The experiment was conducted at plot E-6 of Department of Seed Science and Technology, Gandhi Krishi Vignana Kendra campus, University of Agricultural Sciences, Bangalore during Kharif 2012-13. There were ten treatments with three spacing levels and laid out in factorial randomized block design with three replications. The treatments combinations includes $\mathrm{T}_{1}$ : 25:50:25 RDF NPK kg ha ${ }^{-1}, \mathrm{~T}_{2}:$ 31.25:62.50:31.25 NPK $\mathrm{kg} \mathrm{ha} \mathrm{ha}^{-1}(25 \%$ enhanced dosage $), \mathrm{T}_{3}$ : 37.50:75:37.50 NPK kg ha ${ }^{-1}$ (50\% enhanced dosage), $\mathrm{T}_{4}: 43.75: 87.50: 43.75 \mathrm{NPK} \mathrm{kg} \mathrm{ha}^{-1}(75 \%$ enhanced dosage), $\mathrm{T}_{5}: 50: 100: 100$ NPK kg ha ${ }^{-1}$ (100\% enhanced dosage), $\mathrm{T}_{6}: 25: 50: 25$ NPK kg ha ${ }^{-1}+$ Black gram rhizobia (250 $\left.\mathrm{g} \mathrm{ha}^{-1}\right)+$ PSB- Bacillus megaterium (250 $\left.\mathrm{g} \mathrm{ha}^{-1}\right), \mathrm{T}_{7}: 31.25: 62.50: 31.25 \mathrm{NPK} \mathrm{kg} \mathrm{ha}{ }^{-1}+$ Black gram rhizobia (250 $\left.\mathrm{g} \mathrm{ha}^{-1}\right)+$ PSB- B. megaterium $(250$ $\left.\mathrm{g} \mathrm{ha}^{-1}\right), \mathrm{T}_{8}: 37.50: 75: 37.50$ NPK kg ha ${ }^{-1}+$ Black gram rhizobia $\left(250 \mathrm{~g} \mathrm{ha}^{-1}\right)+$ PSB- B. megaterium $(250 \mathrm{~g}$ $\left.\mathrm{ha}^{-1}\right), \mathrm{T}_{9}: 43.75: 87.50: 43.75$ NPK kg ha ${ }^{-1}+$ Black gram rhizobia (250 $\left.\mathrm{g} \mathrm{ha}^{-1}\right)+$ PSB- B. megaterium $(250$ $\left.\mathrm{g} \mathrm{ha}^{-1}\right), \quad \mathrm{T}_{10}: 50: 100: 100 \mathrm{NPK} \mathrm{kg} \mathrm{ha}{ }^{-1}+$ Black gram rhizobia $\left(250 \mathrm{~g} \mathrm{ha}^{-1}\right)+\mathrm{PSB}-$ B. megaterium $(250 \mathrm{~g}$ $\left.\mathrm{ha}^{-1}\right), \mathrm{S}_{1}: 30 \times 10 \mathrm{~cm}, \mathrm{~S}_{2}: 45 \times 10 \mathrm{~cm}$ and $\mathrm{S}_{3}: 60 \times 10 \mathrm{~cm}$. The calculated quantity of $\mathrm{N}, \mathrm{P}_{2} \mathrm{O}_{5}$ and $\mathrm{K}_{2} \mathrm{O}$ in the form of urea, single super phosphate and muriate of potash, respectively were supplied as per the treatments at the time of sowing. Black gram cv. LBG 625 (Rashmi) seeds were treated with black gram rhizobia and B. megaterium and sown on $4^{\text {th }}$ of August 2012 at an inter and intra row spacing of $30 \times 10,45 \times 10$ and $60 \times 10 \mathrm{~cm}$, respectively. For recording seed quality parameters like Test weight (g), Germination (\%), mean seedling length $(\mathrm{cm})$, mean seedling dry weight (mg), seedling vigour index [SVI-I and SVI-II], electrical conductivity of seed leachate $\left(\mathrm{dSm}^{-1}\right)$, total dehydrogenase activity, protein Content (\%), field emergence (\%) were discussed below,

Test weight (g): Thousand seeds were counted manually from a sample drawn randomly from each treatment in four replications and weighed as per the procedure given by ISTA (Anonymous, 2007). The mean weight of the sample was recorded as thousand seed weight and expressed in grams.

Germination (\%): The germination test was conducted in the laboratory by using between paper methods as per ISTA rules (1985). One thousand seeds in four replicates were placed on germination paper and rolled towels were incubated in germination chamber maintained at $25 \pm 1^{\circ} \mathrm{C}$ and 90 per cent relative humidity. The germinated seedlings were evaluated on fourth and eighth day as first and final count, respectively and

Table 1. Influence of nutrient levels (T) and spacing (S) on seed quality parameters of black gram cv. LBG 625 (Rashmi).

\begin{tabular}{|c|c|c|c|c|c|c|}
\hline $\begin{array}{l}\text { Nutrient } \\
\text { levels }\end{array}$ & $\begin{array}{c}\text { Test } \\
\text { weight (g) }\end{array}$ & $\begin{array}{c}\text { Germination } \\
(\%)\end{array}$ & $\begin{array}{l}\text { Mean seedling } \\
\text { length }(\mathrm{cm})\end{array}$ & $\begin{array}{l}\text { Mean seedling } \\
\text { dry weight (mg) }\end{array}$ & $\begin{array}{l}\text { Seedling vigour } \\
\text { index-I }\end{array}$ & $\begin{array}{l}\text { Seedling vigour } \\
\text { index-II }\end{array}$ \\
\hline$T_{1}$ & 35.51 & 86.60 & 21.60 & 50.86 & 1871 & 440 \\
\hline $\mathbf{T}_{2}$ & 35.67 & 87.00 & 22.94 & 51.71 & 1996 & 450 \\
\hline $\mathbf{T}_{3}$ & 35.76 & 87.37 & 22.50 & 51.27 & 1966 & 448 \\
\hline $\mathbf{T}_{4}$ & 36.27 & 87.40 & 23.58 & 52.54 & 2061 & 459 \\
\hline $\mathbf{T}_{5}$ & 36.02 & 88.14 & 23.19 & 53.73 & 2045 & 473 \\
\hline $\mathbf{T}_{6}$ & 37.60 & 88.42 & 24.15 & 53.54 & 2141 & 473 \\
\hline $\mathbf{T}_{7}$ & 37.36 & 88.80 & 24.29 & 53.76 & 2163 & 478 \\
\hline $\mathbf{T}_{8}$ & 37.87 & 89.30 & 26.40 & 54.70 & 2364 & 488 \\
\hline $\mathbf{T}_{9}$ & 37.87 & 89.80 & 27.43 & 56.10 & 2473 & 504 \\
\hline $\mathbf{T}_{10}$ & 39.27 & 90.60 & 29.20 & 57.99 & 2656 & 525 \\
\hline F test & $*$ & $*$ & $*$ & * & $*$ & $*$ \\
\hline S. Em \pm & 0.07 & 0.37 & 0.13 & 0.27 & 8.77 & 0.85 \\
\hline C.D $(P=0.05)$ & 0.20 & 1.05 & 0.37 & 0.78 & 24.83 & 2.39 \\
\hline \multicolumn{7}{|l|}{ Spacing (cm) } \\
\hline$S_{1}:(30 \times 10)$ & 35.35 & 86.91 & 22.64 & 53.23 & 1968 & 463 \\
\hline$S_{2}:(45 \times 10)$ & 36.03 & 87.64 & 23.85 & 53.28 & 2091 & 467 \\
\hline$S_{3}:(60 \times 10)$ & 39.37 & 90.48 & 27.11 & 54.35 & 2462 & 492 \\
\hline F test & $*$ & $*$ & $*$ & $*$ & $*$ & $*$ \\
\hline S. Em \pm & 0.04 & 0.20 & 0.07 & 0.15 & 6.68 & 0.46 \\
\hline C.D $(P=0.05)$ & 0.11 & 0.57 & 0.20 & 0.42 & 18.90 & 1.31 \\
\hline
\end{tabular}


Table 2. Influence of nutrient levels (T) and spacing (S) on seed quality parameters of black gram cv. LBG 625 (Rashmi).

\begin{tabular}{|c|c|c|c|c|}
\hline Nutrient levels & $\begin{array}{l}\text { Electrical conduc- } \\
\text { tivity }\left(\mathrm{dSm}^{-1}\right)\end{array}$ & $\begin{array}{c}\text { Total dehydrogenase } \\
\text { activity }\left(\mathrm{A}_{480} \mathrm{~nm}\right)\end{array}$ & $\begin{array}{c}\text { Protein content } \\
(\%)\end{array}$ & $\begin{array}{c}\text { Field emergence } \\
(\%)\end{array}$ \\
\hline$\overline{T_{1}}$ & 0.889 & 0.983 & 22.13 & 82.61 \\
\hline $\mathbf{T}_{2}$ & 0.868 & 0.988 & 22.38 & 83.69 \\
\hline $\mathbf{T}_{3}$ & 0.860 & 0.990 & 22.54 & 83.71 \\
\hline $\mathbf{T}_{4}$ & 0.870 & 0.991 & 22.64 & 83.64 \\
\hline $\mathbf{T}_{5}$ & 0.850 & 0.991 & 22.72 & 84.00 \\
\hline$T_{6}$ & 0.844 & 0.991 & 22.70 & 84.10 \\
\hline $\mathbf{T}_{7}$ & 0.840 & 0.992 & 22.88 & 84.68 \\
\hline $\mathbf{T}_{8}$ & 0.832 & 0.993 & 23.03 & 85.46 \\
\hline $\mathbf{T}_{9}$ & 0.822 & 0.997 & 23.05 & 85.83 \\
\hline $\mathbf{T}_{10}$ & 0.813 & 0.998 & 23.16 & 86.56 \\
\hline F test & $*$ & $*$ & $*$ & $*$ \\
\hline S. $\mathbf{E m} \pm$ & 0.0035 & 0.0008 & 0.09 & 0.39 \\
\hline C.D $(P=0.05)$ & 0.0098 & 0.0024 & 0.25 & 1.11 \\
\hline \multicolumn{5}{|l|}{ Spacing (cm) } \\
\hline$S_{1}:(30 \times 10)$ & 0.869 & 0.987 & 22.42 & 83.09 \\
\hline$S_{2}:(45 \times 10)$ & 0.849 & 0.991 & 22.63 & 83.83 \\
\hline$S_{3}:(60 \times 10)$ & 0.829 & 0.997 & 23.10 & 86.36 \\
\hline F test & $*$ & * & $*$ & $*$ \\
\hline S. $\mathbf{E m} \pm$ & 0.0019 & 0.0005 & 0.05 & 0.22 \\
\hline C.D $(P=0.05)$ & 0.0054 & 0.0013 & 0.14 & 0.61 \\
\hline
\end{tabular}

percentage germination was expressed based on normal seedlings.

Mean seedling length (cm): Ten seedlings taken at randomly from each treatment and replication were separated carefully from the paper towel of laboratory germination test and total length of seedlings after removing the cotyledons was measured using metric scale on the germination (Table 1). The mean length of ten seedlings in each treatment and replications was calculated and expressed in centimeters.

Mean seedling dry weight (mg): Ten seedlings from each treatment and replication were used for measuring the mean seedling length was kept in the hot air oven at $85 \pm 1^{\circ} \mathrm{C}$ for 24 hours. The dry weight (mg) was measured and expressed as mean dry weight (mg seedling ${ }^{-1}$ ).

Seedling vigour index [SVI-I and SVI-II]: The seedling vigour index was calculated as per the formula given by Abdul Baki and Anderson (1973).

SVI-I $=$ Germination $(\%) \times$ Mean seedling length (cm).

SVI-II $=$ Germination $(\%) \times$ Mean seedling dry weight (mg).

Electrical conductivity of seed leachate $\left(\mathrm{dSm}^{-1}\right)$ : Twenty five seeds of two replications were taken randomly from each treatment in a beaker. Then the seeds were soaked in $25 \mathrm{ml}$ of distilled water for $24 \mathrm{~h}$ at $25 \pm 10^{\circ} \mathrm{C}$. The steeped water from soaked seeds was collected and the electrical conductivity (EC) of seed leachate was measured in digital conductivity meter (Model: Systronic conductivity meter 306). After subtracting the EC of the distilled water from the value obtained from the seed leachate, the actual EC due to electrolyte was measured and expressed in $\mathrm{dSm}^{-1}$ (Anonymous, 2007).

Total dehydrogenase activity : The total dehydro- genase activity was determined by method described by Perl et al. (1978).

Protein Content (\%): The total soluble protein was estimated as per the method prescribed by Lowry et al. (1951).

Field emergence (\%): One hundred seeds selected at random from each treatment in three replications were used for the field emergence studies. The seeds were sown in well-prepared soil at 2.50 to $3.00 \mathrm{~cm}$ depth and covered with soil. Field emergence count was taken on $8^{\text {th }}$ day after sowing and the emergence percentage was calculated based on the number of seedlings emerged three centimeters above the soil surface.

Field emergence $=$ Number of seedling emergence at $8^{\text {th }}$ day / Total number of seeds sown X 100

\section{RESULTS AND DISCUSSION}

Influence of nutrient levels on seed quality parameters in black gram: Seed quality parameters were highly significant over the control. The crop provided with 50:100:100 NPK kg ha ${ }^{-1}+$ Black gram rhizobia $250 \mathrm{~g} \mathrm{ha}^{-1}+$ PSB- B. megaterium $250 \mathrm{~g} \mathrm{ha}^{-1}$ recorded more test weight (39.27 g), compared to recommended dose of NPK 25:50:25 kg ha ${ }^{-1}(35.51 \mathrm{~g})$ (Table 1).Among the combinations wider spacing of $60 \times 10$ $\mathrm{cm}$ along with an application of 50:100:100 NPK kg $\mathrm{ha}^{-1}+$ Black gram rhizobia $250 \mathrm{~g} \mathrm{ha}^{-1}+$ PSB- $B$. megaterium $250 \mathrm{~g} \mathrm{ha}^{-1}$ recorded more 1000 seed weight (41.60 g) compared to closer spacing $30 \times 10 \mathrm{~cm}$ along with an application of 25:50:25 RDF NPK kg ha${ }^{1}$ (33.53 g) (Table 3).

Significant differences were noticed in germination per cent among the nutrient levels. The highest germination per cent recorded in 50:100:100 NPK kg ha-1+ Black gram rhizobia $250 \mathrm{~g} \mathrm{ha}^{-1}+$ PSB- B. megaterium 


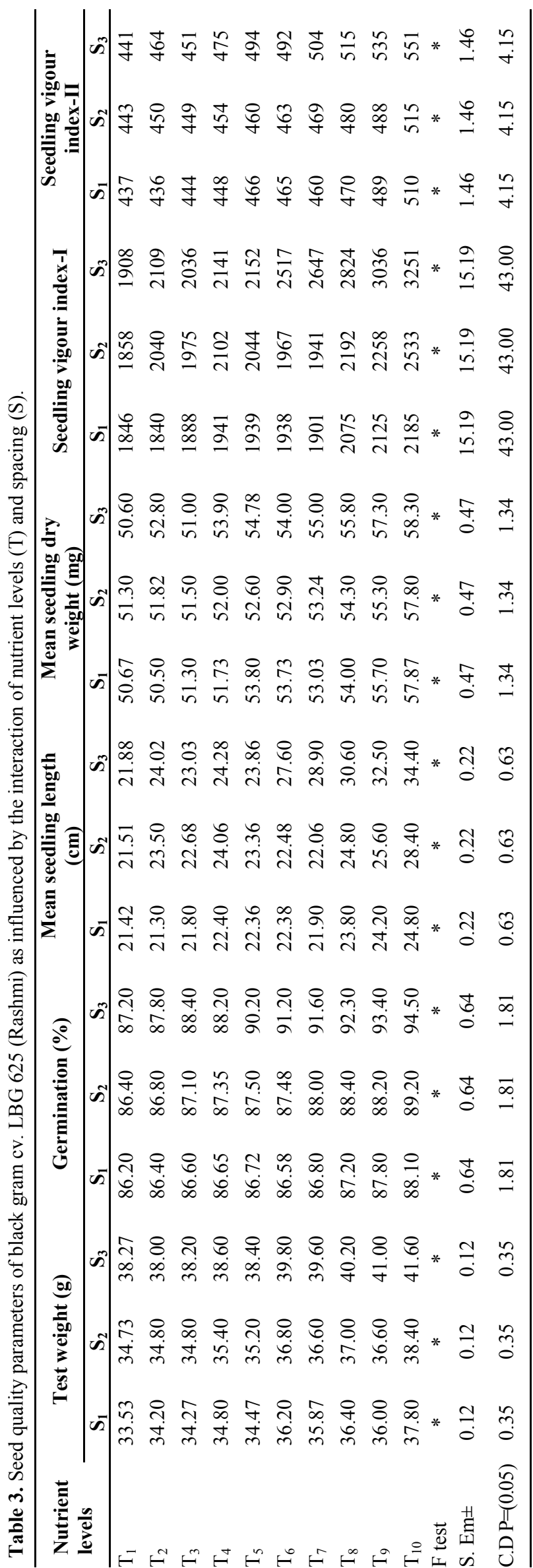

$250 \mathrm{~g} \mathrm{ha}^{-1}(90.60 \%)$ as compared to $25: 50: 25 \mathrm{RDF}$ NPK kg ha ${ }^{-1}(86.60 \%)$ (Table 1). This may be due to presence of higher amount of metabolites, which helps in resumption of embryonic growth during germination. In addition to these metabolites, release of certain enzymes responsible for degradation of macromolecules into micro molecules within the seed These results are also incongruence with Ajay Gupta et al. (2006) in urd bean. Among the combinations wider spacing of $60 \times 10 \mathrm{~cm}$ along with an application of 50:100:100 NPK kg ha ${ }^{-1}+$ Black gram rhizobia $250 \mathrm{~g}$ $\mathrm{ha}^{-1}+$ PSB- B. megaterium $250 \mathrm{~g} \mathrm{ha}^{-1}$ was recorded highest germination per cent $94.50 \%$ compared to closer spacing $30 \times 10 \mathrm{~cm}$ along with an application of 25:50:25 RDF NPK kg ha-1 (86.20\%) (Table 3).

The significant higher root length $(15.77 \mathrm{~cm})$, shoot length $(13.43 \mathrm{~cm})$, mean seedling length $(29.20 \mathrm{~cm})$, mean seedling dry weight $(57.99 \mathrm{mg})$, seedling vigour index-I and II (2,656 and 525) and lower electrical conductivity of seed leachates $\left(0.813 \mathrm{dSm}^{-1}\right)$ and higher TDH $\left(0.998 \mathrm{~A}_{480} \mathrm{~nm}\right)$ were recorded in 50:100:100 NPK kg ha ${ }^{-1}+$ Black gram rhizobia $250 \mathrm{~g}$ $\mathrm{ha}^{-1}+$ PSB- B. megaterium $250 \mathrm{~g} \mathrm{ha}^{-1}$ as compared to 25:50:25 RDF NPK kg ha ${ }^{-1}(12.30 \mathrm{~cm}, 9.30 \mathrm{~cm}, 21.60$ $\mathrm{cm}, 50.86 \mathrm{mg}, 1,871$ and $440,0.889 \mathrm{dSm}^{-1}$ and 0.983 $\mathrm{A}_{480} \mathrm{~nm}$, respectively) (Tables 1 and 2). This might be ascribed to the efficient protein synthesis and better source to sink relationship which resulted in better development of seeds giving rise to higher germination and vigour index. Similar results were reported by Dubay (1998) and Dhage Shubhangi and Kachhave (2010) in soybean. The increased seed recovery per cent might be due to influence of nitrogen, the chief constituent of protein, essential for protoplasm which leads to cell division and cell enlargement given to the parent seed exerted a profound influence on seed filling and relatively high percentage of well filled seeds of largest size.

Among the combinations wider spacing of $60 \times 10 \mathrm{~cm}$ along with an application of 50:100:100 NPK kg ha ${ }^{-1}+$ Black gram rhizobia $250 \mathrm{~g} \mathrm{ha}^{-1}+$ PSB- $B$. megaterium $250 \mathrm{~g} \mathrm{ha}^{-1}$ was recorded highest root length $(17.70 \mathrm{~cm})$, shoot length $(16.70 \mathrm{~cm})$, mean seedling length $(34.40$ $\mathrm{cm})$, mean seedling dry weight $(58.30 \mathrm{mg})$, seedling vigour index-I and II (3251 and 551) and lower electrical conductivity of seed leachates $\left(0.776 \mathrm{dSm}^{-1}\right)$ and higher TDH (1.008) compared to closer spacing $30 \times 10$ $\mathrm{cm}$ along with an application of 25:50:25 RDF NPK $\mathrm{kg} \mathrm{ha}^{-1}(12.21 \mathrm{~cm}, 9.21 \mathrm{~cm}, 21.42 \mathrm{~cm}, 50.67 \mathrm{mg}, 1855$, 437, $0.897 \mathrm{dSm}^{-1}$ and 0.976) (Tables 3 and 4).

Maximum protein content $(23.16 \%)$ was recorded in 50:100:100 NPK kg ha ${ }^{-1}+$ Black gram rhizobia $250 \mathrm{~g}$ $\mathrm{ha}^{-1}+$ PSB- B. megaterium $250 \mathrm{~g} \mathrm{ha}^{-1}$ compared to recommended dose of NPK 25:50:25 kg ha ${ }^{-1}(22.12 \%)$ (Table 2). Increase in protein content due to high uptake of nitrogen and phosphorous by slow and continuous supply through bio fertilizers. The results are in agreement with Mahesh babu et al. (2006) in 
Table 4. Seed quality parameters of black gram cv. LBG 625 (Rashmi) as influenced by the interaction of nutrient levels (T) and spacing (S).

\begin{tabular}{|c|c|c|c|c|c|c|c|c|c|c|c|c|}
\hline \multirow{2}{*}{$\begin{array}{l}\text { Nutrient } \\
\text { levels }\end{array}$} & \multicolumn{3}{|c|}{$\begin{array}{c}\text { Electrical conductiv- } \\
\text { ity }\left(\mathrm{dSm}^{-1}\right)\end{array}$} & \multicolumn{3}{|c|}{$\begin{array}{l}\text { Total dehydrogenase } \\
\text { activity }\left(\mathrm{A}_{480} \mathrm{~nm}\right)\end{array}$} & \multicolumn{3}{|c|}{ Protein content (\%) } & \multicolumn{3}{|c|}{ Field emergence $(\%)$} \\
\hline & $S_{1}$ & $\mathbf{S}_{2}$ & $\mathbf{S}_{3}$ & $\mathbf{S}_{1}$ & $\mathbf{S}_{2}$ & $\mathbf{S}_{3}$ & $\mathbf{S}_{1}$ & $\mathbf{S}_{2}$ & $\mathbf{S}_{3}$ & $\mathbf{S}_{1}$ & $\mathbf{S}_{\mathbf{2}}$ & $\mathbf{S}_{3}$ \\
\hline $\mathbf{T}_{1}$ & 0.897 & 0.892 & 0.878 & 0.976 & 0.983 & 0.991 & 22.24 & 22.31 & 21.80 & 82.22 & 82.40 & 83.20 \\
\hline $\mathbf{T}_{2}$ & 0.881 & 0.868 & 0.856 & 0.984 & 0.988 & 0.993 & 22.25 & 22.28 & 22.60 & 82.77 & 83.50 & 84.80 \\
\hline $\mathbf{T}_{3}$ & 0.873 & 0.858 & 0.850 & 0.987 & 0.989 & 0.994 & 22.37 & 22.44 & 22.80 & 82.78 & 83.45 & 84.90 \\
\hline $\mathbf{T}_{4}$ & 0.885 & 0.868 & 0.856 & 0.988 & 0.989 & 0.995 & 22.40 & 22.54 & 22.98 & 83.05 & 83.48 & 84.40 \\
\hline $\mathbf{T}_{5}$ & 0.867 & 0.848 & 0.834 & 0.988 & 0.990 & 0.995 & 22.44 & 22.60 & 23.12 & 82.89 & 83.50 & 85.60 \\
\hline $\mathbf{T}_{6}$ & 0.864 & 0.843 & 0.825 & 0.988 & 0.991 & 0.994 & 22.39 & 22.57 & 23.14 & 82.69 & 83.55 & 86.05 \\
\hline $\mathbf{T}_{7}$ & 0.863 & 0.838 & 0.818 & 0.988 & 0.993 & 0.995 & 22.50 & 22.76 & 23.38 & 82.82 & 84.03 & 87.20 \\
\hline $\mathbf{T}_{8}$ & 0.861 & 0.832 & 0.804 & 0.989 & 0.994 & 0.996 & 22.47 & 22.83 & 23.80 & 83.57 & 84.73 & 88.07 \\
\hline $\mathbf{T}_{9}$ & 0.855 & 0.824 & 0.788 & 0.990 & 0.995 & 1.006 & 22.56 & 22.94 & 23.64 & 83.98 & 84.37 & 89.13 \\
\hline $\mathbf{T}_{10}$ & 0.844 & 0.818 & 0.776 & 0.990 & 0.996 & 1.008 & 22.60 & 23.04 & 23.84 & 84.17 & 85.28 & 90.24 \\
\hline F test & $*$ & $*$ & $*$ & $*$ & $*$ & $*$ & $*$ & $*$ & $*$ & $*$ & $*$ & $*$ \\
\hline S. $\mathbf{E m} \pm$ & 0.006 & 0.006 & 0.006 & 0.001 & 0.001 & 0.001 & 0.16 & 0.16 & 0.16 & 0.68 & 0.68 & 0.68 \\
\hline C.D $(P=0.05)$ & 0.017 & 0.017 & 0.017 & 0.004 & 0.004 & 0.004 & 0.44 & 0.44 & 0.44 & 1.93 & 1.93 & 1.93 \\
\hline
\end{tabular}

Treatment Details: $\mathrm{T}_{1}: 25: 50: 25$ RDF NPK kg ha- $\mathrm{T}_{2}: 31.25: 62.50: 31.25 \mathrm{NPK} \mathrm{kg} \mathrm{ha}^{-1}$ (25\% enhanced dosage); $\mathrm{T}_{3}: 37.50: 75: 37.50$ NPK kg ha ${ }^{-1}$ (50\% enhanced dosage); $\mathrm{T}_{4}: 43.75: 87.50: 43.75 \mathrm{NPK} \mathrm{kg}^{-1} \mathrm{ha}^{-1}$ (75\% enhanced dosage);

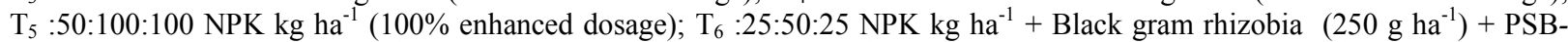
Bacillus megaterium $\left(250 \mathrm{~g} \mathrm{ha}^{-1}\right) ; \mathrm{T}_{7}: 31.25: 62.50: 31.25 \mathrm{NPK} \mathrm{kg} \mathrm{ha}{ }^{-1}+$ Black gram rhizobia $\left(250 \mathrm{~g} \mathrm{ha}^{-1}\right)+$ PSB- Bacillus megaterium $\left(250 \mathrm{~g} \mathrm{ha}^{-1}\right) ; \mathrm{T}_{8}: 37.50: 75: 37.50 \mathrm{NPK} \mathrm{kg} \mathrm{ha}{ }^{-1}+$ Black gram rhizobia $\left(250 \mathrm{~g} \mathrm{ha}^{-1}\right)+$ PSB- Bacillus megaterium $\left(250 \mathrm{~g} \mathrm{ha}^{-1}\right) ; \mathrm{T}_{9}: 43.75: 87.50: 43.75 \mathrm{NPK} \mathrm{kg} \mathrm{ha}{ }^{-1}+$ Black gram rhizobia $\left(250 \mathrm{~g} \mathrm{ha}^{-1}\right)+$ PSB- Bacillus megaterium $\left(250 \mathrm{~g} \mathrm{ha}^{-1}\right) ;$ $\mathrm{T}_{10}: 50: 100: 100 \mathrm{NPK} \mathrm{kg} \mathrm{ha}{ }^{-1}+$ Black gram rhizobia $\left(250 \mathrm{~g} \mathrm{ha}^{-1}\right)+\mathrm{PSB}-$ Bacillus megaterium $\left(250 \mathrm{~g} \mathrm{ha}^{-1}\right) ; \mathrm{S}_{1}: 30 \mathrm{x} 10 \mathrm{~cm} ; \mathrm{S}_{2}$ : $45 \times 10 \mathrm{~cm} ; \mathrm{S}_{3}: 60 \times 10 \mathrm{~cm}$.

soybean where combined use of organic and inorganic fertilizers provided better seed quality parameters over control. Among the combinations wider spacing of $60 \times 10 \mathrm{~cm}$ along with an application of 50:100:100 NPK kg ha ${ }^{-1}+$ Black gram rhizobia $250 \mathrm{~g} \mathrm{ha}^{-1}+$ PSB$B$. megaterium $250 \mathrm{~g} \mathrm{ha}^{-1}$ was recorded highest protein content $(23.84 \%)$ compared to closer spacing $30 \times 10$ $\mathrm{cm}$ along with an application of 25:50:25 RDF NPK $\mathrm{kg} \mathrm{ha}^{-1}(22.24 \%)$ (Table 4).

Maximum field emergence per cent $(86.56 \%)$ was noticed in 50:100:100 NPK kg ha ${ }^{-1}+$ Black gram rhizobia $250 \mathrm{~g} \mathrm{ha}^{-1}+$ PSB- B. megaterium $250 \mathrm{~g} \mathrm{ha}^{-1}$ compared to recommended dose of NPK $25: 50: 25 \mathrm{~kg}$ ha $^{-1}(82.61 \%)$ (Table 2).

Among the combinations wider spacing of $60 \times 10 \mathrm{~cm}$ along with an application of 50:100:100 NPK kg ha-1 Black gram rhizobia $250 \mathrm{~g} \mathrm{ha}^{-1}+$ PSB- $B$. megaterium $250 \mathrm{~g} \mathrm{ha}^{-1}$ was recorded highest field emergence 90.24 $\%$ compared to closer spacing $30 \times 10 \mathrm{~cm}$ along with an application of 25:50:25 RDF NPK kg ha ${ }^{-1}(82.22 \%)$ (Table 4). It might be due to higher food reserves and better source to sink relationship which resulted in better development of seeds giving rise to higher field emergence Similar increased in seed quality parameters with combinations of wider spacing and increased fertilizer levels along with biofertilizers was also reported by Tammanagowda (2002) in green gram.

Spacing differences on seed quality in black gram: Highly significant differences were observed in germination per cent of the spacing. The wider spacing
$60 \times 10 \mathrm{~cm}$ gave higher germination $(90.48 \%)$ than closer spacing $30 \times 10 \mathrm{~cm}(86.91 \%)$ and other seed quality parameters like 1000 seed weight, root length, shoot length, mean seedling length, mean seedling dry weight, seedling vigour index-I and II were also highest in wider spacing $60 \times 10 \mathrm{~cm}(39.37 \mathrm{~g}, 14.90 \mathrm{~cm}$, $12.20 \mathrm{~cm}, 27.11 \mathrm{~cm}, 54.35 \mathrm{mg}, 2,462$ and 492) compared to closer spacing $30 \times 10 \mathrm{~cm}(35.35 \mathrm{~g}, 12.82$ $\mathrm{cm}, 9.82 \mathrm{~cm}, 22.64 \mathrm{~cm}, 53.23 \mathrm{mg}, 1,968$ and 463, respectively) (Table 1) the similar results of increased seed quality parameters with wider spacing where may be attributed to better source to sink relationship of the plants which resulted in better accumulation and assimilation of photosynthates into sinks reported by Dhutraj (2011) in soybean, Selvakumar et al. (2012)in black gram.

Higher TDH $\left(0.997 \mathrm{~A}_{480} \mathrm{~nm}\right)$, protein content (23.08 $\%)$ and field emergence $(86.36 \%)$ and lower electrical conductivity of seed leachate $\left(0.829 \mathrm{dSm}^{-1}\right)$ were noticed in wider spacing $60 \times 10 \mathrm{~cm}$ compared to closer spacing $30 \times 10 \mathrm{~cm}\left(0.987 \mathrm{~A}_{480} \mathrm{~nm}, 22.42 \%, 83.09 \%\right.$ and $0.869 \mathrm{dSm}^{-1}$, respectively) (Table 2).

The similar superior trend in seed quality parameters under wider spacing was also confirmed by Siddaraju et al. (2010) in cluster bean, Dhage shubhangi and Kachhave (2010) in soybean, where in wider spacing may be attributed to better source to sink relationship of the plants which resulted in better accumulation and assimilation of photosynthates into sinks results in higher seed quality parameters. 


\section{Conclusion}

The study result indicated that interaction of nutrient levels and spacing through the application of 50:100:100 + Black gram rhizobia $\left(250 \mathrm{~g} \mathrm{ha}^{-1}\right)+$ PSB$B$. megaterium $\left(250 \mathrm{~g} \mathrm{ha}^{-1}\right)$ with planting geometry 60 $\mathrm{x} 10 \mathrm{~cm}$ recorded highest seed quality parameters over other fertilizer treatments. Therefore conjunctive use of inorganic fertilizers and biofertilizer under wider spacing may be suggested for higher seed quality parameters along with overall betterment of black gram.

\section{ACKNOWLEDGEMENTS}

Authors would like to thank University of Agricultural Sciences, GKVK, Bangalore, Department of Seed Science and Technology, for providing seed and lab facilities for conducting lab work.

\section{REFERENCES}

Abdul Baki, A. A. and Anderson, J. A. (1973). Vigour determination of soybean seeds by multiple criteria. Crop Sci., 13: 630-633.

Ajay Gupta, Vinod Kumar Sharma, Sharma, G. D. and Pankaj Chopra. (2006). Effect of bio fertilizer and phosphorus levels on yield attributes, yield and quality of urd bean (Vigna mungo). Indian J. Agron., 51(2): 142144.

Anilkumar (2004). Standardization of seed production techniques in fenugreek. M.Sc. (Agri) Thesis, Univ. Agri. Sci., Dharwad (India).

Anonymous (2007). International rules for seed testing. Seed Sci. \& Technol., 24: 1-335.

Aulakh, M. S. and Adhya, T. K. (2005). Impact of agricultural activities on emission of greenhouse gases-Indian perspective. In 'International Conference on Soil, Water and Environmental Quality -Issues and Strategies', pp. 319-335 (Indian Society of Soil Science: New Delhi).

Aulakh, M. S. and Grant, C. A. (2008). Integrated nutrient management for sustainable crop production'. (The Haworth Press, Taylor and Francis Group: New York).

Aulakh, M. S., Khurana M. P. S., Singh, D. (2009).Water pollution related to agricultural, industrial and urban activities, and its effects on food chain: Case studies from Punjab. Journal of New Seeds., 10:112-137.

Balasubramanian, V. (1999). Managing soil quality for sustainable rice production. Tamilnadu Rice Research Institute, pp. 11-24.

Dhage Shubhangi, J. and Kachhave, K. G. (2010). Effect of biofertilizers on yield, nutrient content and quality of soybean (Glycine max) under rain fed condition.
J. Oilseeds Res., 27(2): 187-189.

Dhutraj, D.N. (2011). Efficacy of agrochemicals and Rhizobium on different biometric characters, microbial dynamics and yield of soybean. Agric. Res. Technol., 36 (3): 424-426.

Dubay, S. K. (1988).Response of soybean to biofertilizers with and without nitrogen, phosphorus and potassium on swell shrink soil. Indian J.Agron.,43(3): 546-549.

ISTA (1985). International rules for seed testing. Seed Sci \& Technol., 13: 299-513.

Kumar, A., Meena, R. N., Yadav, L. and Gilotia, Y. K. (2014). Effect of organic and inorganic sources of nutrient on yield, yield attributes and nutrient uptake of rice cv. PRH-10. The Bioscan, 9(2): 595-597.

Kumpawat, B. S. (2010). Integrated nutrient management in blackgram (Vigna mungo) and its residual effect on succeeding mustard (Brassicajuncea) crop. Indian $J$. Agric. Sci., 80(1): 76-79.

Lowry, O. H., Rosenburgh, N. J., Farr, A. L. and Randall, R. J. (1951). Protein measurement with the folin phenol reagent. J. Biol. Chem., 193: 265-276.

Maheshbabu, H. M., Ravi Hunje, N. K., Biradar Patil.and Babalad, H. B. (2006), Effect of organic manures on plant growth, seed yield and quality of soybean. Karnataka J. Agric. Sci., 21(2), p. 219-221.

Mandal, Malay, K. and Pramanick, M. (2014). Competitive behavior of component crops in sesame greengram intercropping systems under different nutrient management. The Bioscan, 9(3): 1015-1018.

Perl, M. L., Luria. and Haya. (1978). Biochemical changes in sorghum seeds affected by accelerated ageing. J. Exp. Bot., 29: 497-509.

Sangeeta Shree, Vijay Kumar Singh and Ravi Kumar. (2014). Effect of integrated nutrient management on yield and quality of cauliflower. The bioscan, 9(3):1053 -1058 .

Selvakumar, G, Reetha, S. and Thamizhiniyan, P. (2012). Response of biofertilizers on growth, yield attributes and associated protein profiling changes of black gram (Vigna mungo L. Hepper).World Applied Sci. J., 16 (10): 1368-1374.

Siddaraju, R, Narayanaswamy, S, Ramegowda and Rajendra Prasad, S. (2010). Studies on growth, seed yield and yield attributes as influenced by varieties and row spacing in cluster bean (Cyamopsis tetragonoloba L.). Mysore J. Agric, Sci., 44(1):16-21.

Tammanagowda, P. (2002). Influence of organics on seed yield, quality and storability studies on green gram $\mathrm{Cv}$. China mung. M.Sc. (Agri.) Thesis, Univ. of Agric. Sci.

Dharwad Vavilov, N. I. (1951). The Origin, variation, immunity and breeding of cultivated plants. Ed. Tranil, K.S Chester, Roland Press Company, New York, pp. 45-47. 